Journal of Biotechnology and Strategic Health Research

\author{
Derleme / Review
}

http://dergipark.org.tr/tr/pub/bshr

\title{
SARS-CoV-2 Virüsü ile Enfekte Kritik Düzey Hastaların Tedavisinde Konvelesan (İmmun) Plazma Kullanımı
}

\author{
Convalescent (Immune) Plasma Therapy in the Treatment of Critical Patients \\ Infected with SARS-Cov-2 Virus
}

(iD $\bigotimes$ Tuba Hacıbekiroğlu' ${ }^{1}$, ID Tuğçe Nur Yiğenoğlu², (D) Yasin Kalpakcı ${ }^{1}$

\begin{abstract}
${ }^{1}$ Sakarya Üniversitesi Tip Fakültesi Eğitim ve Araştırma Hastanesi Hematoloji Bilim Dalı
${ }^{2}$ Ankara Sağlık Bilimleri Üniversitesi Dr. Abdurrahman Yurtaslan Onkoloji Eğitim ve Araştırma Hastanesi ORCID ID: Tuba Hacıbekiroğlu 0000-0003-1814-5972, Tuğçe Nur Yiğenoğlu 0000-0001-9962-8882, Yasin Kalpakc1 0000-0001-6944-9808

*Sorumlu Yazar / Corresponding Author: Doç. Dr. Tuba Hacıbekiroğlu, e-posta / e-mail: hacibekiroglu@sakarya.edu.tr

Geliş Tarihi / Received : 18-04-2020 Kabul Tarihi / Accepted: 24-04-2020 Yayın Tarihi / Online Published: 30-04-2020

Atıf Gösterimi/How to Cite: Hacıbekiroğlu T., Yiğenoğlu T.N., Kalpakcı Y. SARS-CoV-2 Virüsü ile Enfekte Kritik Düzey Hastaların Tedavisinde Konvelesan (İmmun) Plazma Kullanımı, J Biotechnol and Strategic Health Res. 2020;1(Özel Sayı):128-134

$\ddot{\mathrm{Oz}}$

Çin Halk Cumhuriyetỉnin Wuhan Eyaletinde yarasadan insana bulaş yolu ile tesbit edilen coronavirüs ailesinden Severe Acute Respiratory Syndrome Coronavirus 2 (SARS-CoV-2) virüsü çok hızlı bir yayılım göstererek çok kısa bir sürede tüm dünyada etkisini göstermiştir.11 Şubat 2020 tarihinde bu virüsün yol açtığı hastalı̆̆ı coronovirüs hastalığı (COVID-19) olarak adlandıran Dünya Sağlık Örgütü (WHO) 11 Mart 2020 tarihinde bu salgın hastalığı pandemi olarak ilan etmiştir. Konvelesan plazma (KP) tedavisi tarihteki salgın hastalık dönemlerinde kullanılmış, etkili olduğu gösterilmiş bir pasif antikor tedavisidir. Konvelesan plazmanın etki mekanizmaları arasında virüsü direkt bağlayarak nötralize etmek, kompleman aktivasyonu, antikor bağımlı sellüler sitotoksisite ve/veya fagositoz yollarıyla virüs eliminasyonunu başlatmak sayılabilir. Nötralizan antikorlar bu etki mekanizmalarında çok önemlidir. Virüsü inaktive ederek viral replikasyonu engellemesi iyileşmedeki en önemli noktadır. Bu yüzden KP da nötralizan antikor titresi ölçümü önemlidir. Nötralizan olmayan antikorların viral replikasyonu durdurmadığı invitro olarak gösterilmiş ve bu antikorların profilakside kullanılabileceği, iyileşmede destekleyici etkileri olduğu öne sürülmüştür. COVİD-19 hastalığında yapılan çalışmalarda da KP nın etkili olduğu görülmüştür. Ülkemizde ve Amerika’da yakın zamanda tedavi endikasyonu alan bu tedavi yönteminin uygulama kriterleri her iki ülke tarafından belirlenmiştir. Uygun donörlerden alınarak, fayda görebilecek hastalara nakledilen konvelesan plazma tedavi sonuçları merakla beklenmektedir.
\end{abstract}

Anahtar Konvelesan (İmmun) Plazma, Plazma tedavisi, Kritik Hasta, SARS-CoV-2.

Kelimeler

\begin{abstract}
Severe Acute Respiratory Syndrome Coronavirus 2 (SARS-CoV-2) virus, which is detected by the transmission from bat toperson in Wuhan Province of the People's Republic of China, has shown its effect all over the world in a very short time. On February 11, 2020, The World Health Organization (WHO), which called the virus-induced disease Coronavirus Disease (COVID-19) and declared this epidemic disease as a pandemic on March 11, 2020. Convalescent plasma (CP) therapy is a passive antibody therapy that has been shown to be effective during periods of epidemic history. Mechanisms of CP include direct binding and neutralizing virus, complement activation, initiation of virus elimination by antibody dependent cellular cytotoxicity and / or phagocytosis. Neutralizing antibodies are very important in these mechanisms of action. The most important point in recovery is the inactivation of the virus and the prevention of viral replication. Therefore, measurement of neutilizing antibody titer is important in CP. It has been shown in vitro that non-neutralizing antibodies do not stop viral replication and it has been suggested that these antibodies can be used in prophylaxis and have supportive effects in recovery. Instudies conducted in COVID-19 disease, CP was also found to be effective. The application criteria of this treatment method, which recently received treatment indication in our country and in the USA, were determined by both countries. The results of convalescent plasma treatment, which are transferred from the appropriate donors to patients who may benefit, are eagerly awaited.
\end{abstract}

Keywords Convalescent (Immune) Plasma, Plasmatherapy, Critical Patients, SARS-Cov-2 Virus 


\section{GIIRIŞ}

İlk olarak Aralık 2019’ da Çin Halk Cumhuriyeti'nin Wuhan Eyaletinde yarasadan insana bulaş yolu ile tesbit edilen coronavirüs ailesinden Severe Acute Respiratory Syndrome Coronavirus 2 (SARS-CoV-2) virüsü çok hızlı bir yayılım göstererek çok kısa bir sürede tüm dünyada etkisini göstermiştir. Virüsün makalenin yazım aşamasında dünya üzerinde 185 ülke/ bölgede, 2 milyon kişiyi enfekte ettiği ve 132 bin kişinin ölümüne neden olduğu gösterilmiştir ${ }^{1} .11$ Şubat 2020 tarihinde bu virüsün yol açtı̆̆ hastalığı COVID-19 olarak adlandıran Dünya Sağlık Örgütü (WHO) 11 Mart 2020 tarihinde bu salgın hastalığı pandemi olarak ilan etmiştir ${ }^{2}$. Aradan geçen 4 ay içinde bu virüse karşı etkin ve tedavi edici bir ajan halen bulunmamaktadır. Tatbik edilen ilaçlar ve oluşturulan algoritmalar vaka bazlı yapılan çalışmalar ve önceden tecrübe edilmiş yöntemlerden ibarettir. Konumuz olan konvelesan plazma (KP) tedavisi tarihteki salgın hastalık dönemlerinde kullanılmış, etkili olduğu gösterilmiş bir pasif antikor tedavisidir. İyileşmiş hastaların enfekte olduğu patojene karşı geliştirmiş olduğu antikorları içeren plazmasının tedavi amaçlı aktif hastalığı olan kişilerde kullanımı pasif antikor tedavisi olarak adlandırılmaktadır. Tarihteki sürecine bakacak olursak hepatit, kızamık, kabakulak, polio gibi hastalıklarda temas sonrası profilaktik olarak, influenza, SARS-CoV, Middle East Respiratory Syndrome [MERS], Ebola gibi hastalıklarda ise tedavi amaçlı kullanıldığı görülmektedir. ${ }^{3-8}$

Konvelesan plazma pandemi koşullarında kesin ve kalıcı bir tedavi (aşı, immunglobulin, ilaç vb.) bulunana kadar oldukça etkili fakat kısa vadeli bir çözümdür. Konvelesan plazmanın etki mekanizmaları arasında virüsü direkt bağlayarak nötralize etmek, kompleman aktivasyonu, antikor bağımlı selüler sitotoksisite ve/veya fagositoz yollarıyla virüs eliminasyonunu başlatmak sayılabilir. Nötralizan antikorlar bu etki mekanizmalarında çok önemlidir. Virüsü inaktive ederek viral replikasyonu engellemesi iyileşmedeki en önemli noktadır. Bu yüzden KP ‘da nötralizan antikor titresi ölçümü önemlidir. Nötralizan olmayan antikorların viral replikasyonu durdurmadığı in vitro olarak gösteril- miş ve bu antikorların profilakside kullanılabileceği, iyileşmede destekleyici etkileri olduğu öne sürülmüştür.9,10

21. yüzyıl içinde yaşanmış iki önemli salgında KP tedavi olarak kullanılmıştır. Bunlardan biri 2003 yılında yaşanan SARS-1, diğeri 2012 yılında yaşanan MERS salgınıdır. ${ }^{11,12}$ SARS-1 salgınında Hon-Kong da 80 hastalık yapılan araştırmada KP verilme zamanına dikkat çekilmiş ve semptom başlangıcından sonraki ilk 14 gün içinde verilen plazmaların sonuçlarının çok daha iyi olduğunu, kullanılan hastaların çoğunun 22. günden önce taburcu edilebildikleri belirtilmiştir. $^{13}$

Geçmişteki elde edilen olumlu sonuçlar göz önüne alınarak COVID-19 da ilk deneyimler hastalığın merkezi olan Çin Halk Cumhuriyeti’nden geldi. COVİD-19 da ilk KP 'nın 1 Şubat 2020 tarihinde Wuhan 'da toplandığı ve 9 Şubat 2020 tarihinde bir hastaya verildiği raporlanmıştır. $^{14}$ Peşi sıra vaka serisi şeklinde yayınlanan iki çalışmada KP’nın oldukça etkili bir yöntem olduğu gösterilmiştir. Duan ve arkadaşlarının yaptıkları çalışmada $200 \mathrm{ml}$ KP ortalama 16,5. günde, 10 hastaya uygulanmıştır. ${ }^{15}$ Nötralizan antikor titreleri 1:640 üzerinde olan KP uygulamasının ardından 3 gün içinde ateş, öksürük, nefes darlığı şikayetleri gerileyip, oksijen saturasyonlarının arttı̆̆ gösterilmiştir. Klinikle eş zamanlı olarak lenfosit sayısında artış ve CRP değerlerinde anlamlı bir düşüş, bir haftanın sonunda ise akciğerin radyolojik bulgularında gerileme olduğu saptanmıștır. KP uygulanmasından 1-2 gün sonra tüm hastalarda nötralizan antikor titrelerinin 1:640 üzerine çıkması ve 7 hastada serum SARS-CoV-2 RNA sinın negatif bulunması bu çalışmanın dikkat çekici sonuçları arasındadır. Yine bu çalışmada KP donörlerinin kanları incelendiğinde 40 donörün 39'unda nötralizan antikor titresi1:160 üzerinde bulunmuş. Yani iyileşen hastaların hemen hepsinin plazmasında nötralizan antikor geliştiğini bu çalışma ile desteklenmiştir. Shen ve arkadaşlarının yaptığı diğer çalışmada KP alan 5 kritik düzey hasta sonuçları verilmiştir. ${ }^{16}$ Virüs spesifik antikor (IgG) titresi 1:1000, nötralizan antikor $>40$ olduğu gösterilmiş ve KP ortalama olarak 10 
ile 22. günler arasında verilmiş. İlk 3 gün içinde 5 hastadan 4 'ünde ateşin gerilediği, 12 gün içerisinde ise virüsün kanda negatifleştiği ve 2 hafta içinde 3 hastanın mekanik ventilasyondan ayrıldığ 1 gözlemlenmiştir. Vaka sayısı azlığı ve randomize bir çalışma olmamasına rağmen alınan olumlu sonuçlar, KP kullanımını tedavi algoritmaları arasına almış ve Amerikan Gıda ve İlaç Yönetimi (FDA) 24 Mart 2020 tarihinde KP' nin kritik hastalarda kullanımını onayladığını açıklamıştır. ${ }^{17}$ Çalışmaların da desteklediği üzere KP tedavisi kısa zamanda uygulanabilen, uygun zaman diliminde verildiğinde sonuçlarının oldukça yüzgüldürücü olduğu bir tedavi yöntemidir. Fakat bu tedavinin standartizasyonunu yapmak oldukça zordur. Her ülkenin teknik şartları birbirinden oldukça farklıdır. Bunun yanında yeni karşılaştığımız bu virüsü tesbit etmede ve antikor titrelerinin ölçümünde kullanılan testlerin validasyonu da net değildir. Nötralizan antikorların tedavide önemli rol oynadığ 1 bilinmekle birlikte total antikorların yada alt gruplarının (IgG,A,M) optimal bir ölçüm olup olmadığı da netlik kazanmamıştır. Diğer insan koronavirüs çalışmalarına bakıldığında IgG3, IgM ve IgA’nın daha az çapraz reaksiyon verdiği gösterilmiştir. ${ }^{18}$ Başka bir grubun COVİD-19 da yaptığı çalışmada ise IgG ve IgM nin kombine tesbitinin sensitivite ve spesivitesi sırasıyla \%88 ve \%90 olarak bulunmuştur. ${ }^{19}$ COVİD-19 da serokonversiyonun semptomların ortaya çıkışından 8-21 gün sonrasında oluştuğu gösterilmiştir. ${ }^{20}$ Duan ve arkadaşlarının yaptığı çalışmada 14. günden sonra toplanan hasta plazmalarında yüksek titrede nötralizan antikor tesbit edilmiştir. Sonuç olarak KP nın etkinliğinde içinde bulundurduğu nötralizan antikor titresinin ve plazmanın hastaya uygulandığı zamanın önemli bir rol oynadığı aşikardır. Tüm bunlar ışığında FDA konvelesan plazma için hasta endikasyonlarını ve ürün standartlarını açık şekilde belirlemiş ve yapılabiliyorsa nötralizan antikor titresinin1:320 üzerinde olması gerektiğini belirtmiştir. Ülkemiz de de Nisan ayı içerisinde Sağlık Bakanlığımız COVİD-19 İmmün (Konvelesan) Plazma Tedarik ve Klinik Kullanım Rehberini yayınlamış ve alacak hasta grubu, ürün özellikleri ve donör kriterlerini standartize etmiştir. ${ }^{21}$ Bu kapsamda Kızılay veAferez merkezine sahip hastaneler tarafından, uygun donorlerden, aferez yöntemi kullanılarak KP toplanmasına ve toplanan plazmanın uygun hasta kriterlerini taşıyan olgularda kullanılmasına karar verilmiştir.

\section{Donör Uygunluk Kriterleri ve Donasyon Öncesi Yapılması Gereken İşlemler}

T.C. Sağlık Bakanlığı Sağlık Hizmetleri Genel Müdürlüğü Kan ve Kan Ürünleri Dairesi Başkanlığı COVİD-19 İmmün (Konvelesan) Plazma Tedarik ve Klinik Kullanım Rehberi baz alınarak hazırlanmış bu bölümde donörlerin öncelikle Ulusal Kan ve Kan Bileşenleri Hazırlama, Kullanım ve Kalite Güvencesi Rehberi ile Avrupa İlaç ve Sağlık Bakım Kalite Direktörlügü (EDQM) talimatları doğrultusunda standart bağışçı seçim kriterlerine uygunluğu değerlendirilmelidir.Temel olarak kan bağışçısı olabilme kriterlerini taşıyan donör adaylarından ek olarak aşağıda tanımlanan kriterleri sağlaması beklenir;

- Tüm bağışçı adaylarının mutlaka COVID-19 enfeksiyonu tanısı aldığına dair pozitif laboratuvar test sonucunun olması (nazofarengeal sürüntü, moleküler kan testleri ile),

- Bağışçı adayı, hastanede yatarak tedavi gören kişi ise taburculuk öncesi alınan (24 saat ara ile) iki nazofarenks sürüntü örneğinin SARS-CoV-2 moleküler test sonuçlarının "NEGATİF” bulunması ve negatif test sonucundan sonra klinik olarak tam iyileşmesinin üzerinden en az 14 gün geçmiş olması. Taburcu edilirken test yapılmayan hastalar veya COVID-19 tanısı almış ancak tedavi ve/veya karantina sürecini evde tamamlayan bağış̧̧ı adaylarının klinik olarak tam iyileşmesinin üzerinden en az 28 gün geçmiş ve bağ 1 ş öncesinde nazofarenks sürüntü örneğinden çalışılmış SARS-CoV-2 moleküler test sonucunun "NEGATIF" olmas1,

- Yasal mevzuata uygun olarak kan bağışçısı olabilmesi için gerekli sorgulamanın yapılması; Kısa Fizik Muayene, Aferez Bağışçısı Bilgilendirmiş Onam Formu’nun Doldurulması, COVID-19 İmmün Plazma Gönüllü Bağışçıları İçin Ek Sorgulama Formu (Ek-1) 
ile Aferez Kan Bağışçısı Sorgulama Onam Formu'nun birlikte doldurulması ve değerlendirilmesi,

- Bağışçıdan, immün plazma bağışını gönüllülük esasina göre yaptığına dair "COVID-19 İmmün Plazma Gönüllü Bağışçı Onam Formunu” doldurması (EK2),

- Bağışçı adaylarında, mikrobiyolojik tarama testlerinin (serolojik olarak HBsAg, anti-HCV, anti-HIV 1-2 ve anti-sifiliz Ab testleri ve yapılabiliyorsa HBV-DNA, HCV-RNA, HIV 1,2-RNA, Nükleik Asit Amplifikasyon Tarama (NAT) testi çalışılması,

- İmmün plazma bağışçılarının tercihen erkeklerden, gebe kalmamıs kadınlardan ve kan transfüzyon yapılmamış kişilerden seçilmesi. Doğum ya da düşük yapmış kadınların ve kan transfüzyon yapılmış kişilerin bağış̧̧ı olabilmesi için HLA antikorları açısından taranması ve negatif olduğunun gösterilmesi,

- COVID-19 İmmün Plazma bağışçılarının antikor tarama (indirekt coomb's) test sonucu negatif olması

- Plazmaların anti-SARS-CoV-2 nötralizan antikor titresi 1:80 (FDA klavuzunda optimal düzey>1:320 olarak tanımlanmıştır) ve üzerinde olanların seçilmesi veya ELISA testi ile bu değere karşılık gelen eşik değer literatürde tanımlandıktan sonra bu eşik değerin üzerinde antikor değeri olanların seçilmesi (test yapılabilir hale gelene kadar, bu ölçüm yapılmadan alınan plazmalardan antikor titresi tayini için numune ayrılması ve dondurularak saklanması),

- Transfüzyon güvenliğini mümkün olan en üst düzeye çıkarabilmek adına, öneri olarak, alınan plazmaların "Patojen İnaktivasyonu"na tabi tutulması,

- İmmün plazma bağışının, ilk bağışın yapıldığı tarih başlangıç tarihi olarak kabul edilmek kaydıyla, 7-10 günde bir olmak üzere bir ay içerisinde en fazla $3 \mathrm{kez}$ yapılabilmesi,

- Plazma bağışı için aferez yönteminin seçilmesi,

- Donör ve alıcinın ABO / Rh kan grubunun tam uyumlu olması,

- Bağışçılardan antikoagülan solüsyon miktarı göz ardı edilerek 200-600 ml arasında plazma toplanması, 200 ml'nin üzerinde bileşen toplanması halinde bileşenlerin, 200 ml.'lik bölünmüş bileşen olarak ayrı ayrı etiketlenmesi ve $200 \mathrm{ml}$ plazmanın 1 ünite olarak tanımlanması,

- Takip edilebilirlik açısından alınan plazma bileşenleri ISBT kodlama sistemi kullanılarak, Türk Kızılay’ından provizyon alınarak, etiketlenmiş (COVID-19 İmmün Plazma) olması ve izlenebilirlik açısından Ulusal Mevzuata uygun olarak şahit numunelerin saklanmaS1,

- Toplanan plazmanın işlemi takiben 6 saat içerisinde likit plazma formunda (dondurulmadan), hastaya kullanılacak ise IŞINLANMASI, likit formda kullanılma imkanı olmayan bileşenler için "Kan Hizmet Birimleri İçin Ulusal Standartlar” rehberine uygun olarak aferez işleminin tamamlanmasından sonraki ilk 6 saat içinde dondurma işlemine başlanılmış olması.

Yukarıda istenen kriterlerin sağlanması ve tariflenen işlemlerin uygulanması sonrasında donörden 200-600 ml arasındaki miktarda (donörün vücut ağırlığı ile değişkenlik gösterir) plazma aferez yöntemi ile toplanır. Hastaya verilecek optimal plazma dozunun ne kadar olduğu netleşmemiş bir noktadır. Genelde çalışmalarda $200 \mathrm{ml}$ bir ünite olarak tanımlanmış ve hastalara ortalama 1-2 Ü plazma uygulanmıştır. Konvelesan plazma ile verilen antikorların etkinlik süresi hakkında da net bir bilgi yoktur. Tahmini olarak bu sürenin haftalardan birkaç aya kadar devam edebileceği öngörülmüştür.

\section{Konvelesan Plazma Tedavisi için Uygun Hasta Seçim Kriterleri}

Tedavi algoritmaları içinde yerini alan ve destek tedavisi olarak kullanılacak olan KP tedavisi için uygun hasta seçimi oldukça önemli bir noktadır. Çin'de yapılan çalışmalarda KP tedavisinin en fazla, semptom başlangıcından itibaren 7.-14. günler arasında etkin olduğu gözlemlenmiştir. Genelde hastane yatışlarının 4.-5. günler arasında olduğu, klinik ve laboratuvar değerlerinin 7.-10. günler arasında kötüleştiği ve 7.-10.günler sonrasında hastanın yoğun ba- 
kım ihtiyacı olduğu görülmüştür. 7.-10. günler arası dönem hastanın antikor yapımının başladığ 1 ve virüse karşı savaşı başlattığı dönemdir ve çalışmalarda bu dönemde sitokin firtınası olduğu gösterilmiştir. ${ }^{22}$ Tam olarak bu dönemin başlangıcında yani 7.-14. günler arasında, hastaya KP uygulaması yapılabilirse oldukça yüz güldürücü yanıtların alındığı çalışmalarla da gösterilmiştir. Bu anlamda hem FDA hem de Sağlık Bakanlığı’mızın yayınlamış olduğu rehberde uygun hasta kriterleri yayınlanmıştır. Bu kriterler arasinda;

- Kesin (moleküler laboratuvar test pozitif) veya kuvvetle olası (klinik/radyolojik bulgular +, PCR bekleniyor) COVID-19 tanisı olan

- 18 yaşın üzeri

- Hastalığın ilk 14 gününde, tercihen semptomların başlamasından 7-10 gün sonra

- Serum IgA düzeyi normal olan

$\mathrm{VE}$

- Kritik düzey hastalık belirteçlerinden birisi mevcut hastalar:

- Solunum Sayıs1 $\geq 30 / \mathrm{dk}$

- Oksiyensaturasyonu sO2 $\leq \% 93$

- Parsiyelarteriel O2 basinc1 (Pa O2) / Fi O2 <300 mmHg

- 5 litre/dakika ve üstünde nazal oksijen desteğine rağmen oksijen saturasyonu $<\% 90$

- 5 litre/dakika ve üstünde nazal oksijen desteğine rağmen parsiyel oksijen basinc1 $<70 \mathrm{mmHg}$

- Mekanik ventilasyon ihtiyacı

- 24-48 saat içinde \%50' den fazla akciğer infiltrasyonunda artış görülmesi

- Sepsis İlişkili Organ Yetmezliği Değerlendirmesi Skoru (Sepsis Releated Organ Failure Assessment = SOFA Skoru) $\geq 2$

- Kan laktat düzeyi $>2 \mathrm{mmol} / \mathrm{L}$

- Vazopressör ihtiyacı olması

- Hızlı klinik progresyon beklenen hastalara, kötü prognostik parametreleri olanlara (lenfopeni; CRP, ESH, ferritin, LDH, D-dimer yüksekliği)

- Yoğun bakım şartı gerektiren organ yetmezliği, solunum yetmezliği, septik şok tablosu
Konvelesan Plazma için uygun hastalar olarak nitelendirilebilirler.

\section{Konvelesan Plazma Kullanımının Potansiyel Riskleri}

Konvelesan Plazma uygulaması genel anlamda herhangi bir kan ürünü transfüzyonunun beraberinde getirdiği riskler ile benzer riskler taşımaktadır. Bu riskler arasında enfeksiyonlar (viral geçiş, bakteriyel kontaminasyon), immünolojik reaksiyonlar, non-hemolitik transfüzyon reaksiyonları, transfüzyon ilişkili dolaşım yüklenmesi (TACO), transfüzyon ilişkili akut akciğer hasarı (TRALI), Antikor bağımlı enfeksiyon artışı (ADEI) karşılaşılabilecek tablolardır. ${ }^{23}$ Virüsün oluşturduğu akciğer hasarından dolayı TRALİ için yakın takip ve mümkünse erkek donörlerden plazma hazırlanması, kadın donörlerin ise doğum yapmamış olanlarının, HLA antikor taraması yapılarak işleme alınması önerilmektedir. ${ }^{24}$ İleri yaş, kardiyak ve renal fonksiyon bozukluğu olan hastalarda özellikle sıvı yüklenmesi açısından (TACO) dikkatli olunmalıdır. Olası virüs transfer riski için şimdiye kadar olan deneyimlerde SARSCoV2 virüsünün kan yolu ile bulaşı gösterilmemiştir. Ülkemiz şartlarında henüz üründe patojen inaktivasyonu yapılamadığı için, donörlerin kanıtlanmış negatif moleküler test sonuçları önem arzetmektedir. Buna ek olarak kullanılan plazma profilaktik olarak değil, tedavi olarak kullanıldığg için, zaten vücudunda bu virüsü taşıyan kişiye plazma verilirken bulaş riskinin bir anlamının teorik olarak olmayacağı kanaati yaygındır. Wuhan'da Ocak-Mart 2020 ayları arasında 2430 adet kan bağışçısının taramasında sadece bir bağışcıda asemptomatik SARS-CoV-2 RNA pozitif verici saptanmıştır. ${ }^{25}$ Semptomatik hastaların kanlarında SARSCoV-2 RNA pozitifliğinin \%1 olarak bulunması olası bulaş riskinin çok düşük olduğunu destekler niteliktedir. ${ }^{26}$ Antikor bağımlı enfeksiyon artışı (ADEI) SARS-CoV-2 enfeksiyonu için teorik bir yan etkidir. ${ }^{27}$ ADEI daha önce geçirilmiş farklı bir koronavirüs serotipine karşı geliştirilmiş antikor varlığına bağlı olarak kliniğin şiddetlenmesi olarak tanımlanır. Koronavirüsler için ADEI nadir tanımlanmış bir risktir ve SARS, MERS veya COVID-19 'da KP kullanımı sonucu gelişen bir ADEI tablosu bildirilmemiştir. ${ }^{28,29}$ 
J Biotechnol and Strategic Health Res. 2020;1(Özel Sayı):128-134

Sonuç olarak COVİD-19 için günümüzde henüz bulunabilmiş bir tedavi yöntemi, aşı, hiperimmunglobulin mevcut değildir. Bu şartlar altında dünyada ve ülkemizde yeni tedavi ajanları hızla araştırılıp, geliştirilirken yapılabilecek en etkin destek tedavisi yöntemi konvelesan (immun) plazma uygulamasıdır. Tarihte daha önceki salgın dönemlerinde de etkinliği gösterilmiş olan bu pasif antikor tedavisinin COVİD-19 pandemisinde de olumlu sonuçlar verdiği çalışmalarla gösterilmiştir. Ülkemizde de çok kısa süre önce başlatılan KP tedavi uygulamasının sonuçlarının yakın zamanda açıklanacağı kanaatindeyiz. Etkili ve güvenli bir tedavi yöntemi bulunana kadar mevcut diğer tedavi yöntemlerine (antiviral, antikoagülan vb.) destek amaçı KP uygulamasının hızlı ve güvenli bir tedavi yöntemi olarak görünmektedir. 
J Biotechnol and Strategic Health Res. 2020;1(Özel Sayı):128-134

HACIBEKİROĞLU, YİĞENOĞLU, KALPAKCI., Konvelans Plazma Tedavisi

\section{Kaynaklar}

1. JHU. Coronavirus COVID-19 Global Casesbythe Center forSystems Science and Engineering at Johns Hopkins. https://coronavirus.jhu.edu/map.html. Updated April 4, 2020 Accessed April 5, 2020.

2. WHO. Rolling updates on corona virüs disease (COVID-19). https://www.who.int/emergencies/diseases/novel-coronavirus-2019/events-as-they-happen. Updated March 17, 2020 Accessed March 18, 2020.

3. Casadevall $A$, and Scharff MD. Return to the past: the case for antibody-based therapies in infectious diseases. Clin Infect Dis. 1995;21(1):150-61.

4. Stokes J, Jr., WolmanIj, CarpenterHc, AndMargolis J. Prophylactic Use Of Parents' Whole Blood In Anterior Poliomyelitı: Philadelphia Epıdemic Of 1932. American Journal Of Diseases Of Children. 1935;50(3):581-95.

5. Hung IF, To KK, Lee CK, Lee KL, Chan K, Yan WW, et al. Convalescent plasma treatment reduced mortality in patients with severe pandemic influenza A (H1N1) 2009 virus infection. Clin Infect Dis. 2011;52(4):447-56.

6. Zhou B, Zhong $N$, and Guan Y. Treatment with convalescent plasma for influenza $A$ (H5N1) infection. N Engl J Med. 2007;357(14):1450-1.

7. Zhang JS, Chen JT, Liu YX, Zhang ZS, Gao H, Liu Y, et al. A serological survey on neutralizing antibody titer of SARS convalescent sera. J MedVirol. 2005;77(2):147-50.

8. Ko JH, Seok H, Cho SY, Ha YE, Baek JY, Kim SH, et al. Challenges of convalescent plasma infusion therapy in Middle East respiratory coronavirus infection: a single centre experience. Antivir Ther. 2018;23(7):617-22.

9. Van Erp EA, Luytjes W, Ferwerda G, andvanKasteren PB. Fc-Mediated Antibody Effect or Functions During Respiratory Syncytial Virus Infection and Disease. Front Immunol. 2019;10:548.

10. Gunn BM, Yu WH, Karim MM, Brannan JM, Herbert AS, Wec AZ, et al. A Role for Fc Function in Therapeutic Monoclonal Antibody-Mediated Protection against Ebola Virus. Cell Host Microbe. 2018;24(2):221-33.e5

11. Yeh KM, Chiueh TS, Siu LK, Lin JC, Chan PK, Peng MY, et al. Experience of using convalescent plasma for severe acute respiratory syndrome among healthcare workers in a Taiwan hospital. J Antimicrob Chemother. 2005;56(5):919-22

12. Ko JH, Seok H, Cho SY, Ha YE, Baek JY, Kim SH, et al. Challenges of convalescen plasma infusion therapy in Middle East respiratory coronavirus infection: a single centre experience. Antivir Ther. 2018;23(7):617-22.

13. Cheng Y, Wong R, Soo YO, Wong WS, Lee CK, $\mathrm{Ng} \mathrm{MH,} \mathrm{et} \mathrm{al.} \mathrm{Use} \mathrm{of} \mathrm{convalescent} \mathrm{plasma}$ therapy in SARS patients in Hong Kong. Eur J Clin Microbiol Infect Dis. 2005;24(1):44-6.

14. China puts 245 COVID-19 patients on convalescent plasma therapy. News release. Xinhua. February 28, 2020. Available from: URL: http://www.xinhuanet.com/english/2020-02/28/c_138828177. htm. Accessed, March 10, 2020

15. Duan K, Liu B, Li C, Zhang H, Yu T, Qu J, et al. The feasibility of convalescent plasma therapy in severe COVID-19 patients: a pilot study. Available from: URL: https://www.medrxiv.org/content/10.1101/ 2020.03.16.20036145v1.full.pdf+html. Accessed March 23, 2020.
16. Shen C, Wang Z, Zhao F, Yang Y, Li J, Yuan J, et al. Treatment of critically ill patients with COVID-19 with convalescent plasma. JAMA. Available from: URL: https://jamanetwork. com/journals/jama/fullarticle/2763983. Accessed, March 27, 2020.

17. FDA. Investigational covid-19 convalescent plasma-emergency INDs. https://www.fda. gov/ vaccines-blood-biologics/investigational-newdrug-ind-or-device-exemption-ideprocesscber/investigational-covid19-convalescent-plasma-emergency-inds

18. Amanat F, Nguyen T, Chromikova V, Strohmeier S, Stadlbauer D, Javier A, et al. A serological assay to detect SARS-CoV-2 seroconversion in humans. medRxiv. 2020:2020.03.17.20037713.

19. Li Z, Yi Y, Luo X, Xiong N, Liu Y, Li S, et al. Development and Clinical Application of A Rapid IgM-IgG Combined Antibody Test for SARS-CoV-2 Infection Diagnosis. J Med Virol. 2020.

20. OKBA NMA, Muller MA, Li W, Wang C, Geurtsvan Kessel CH, Corman VM, et al. SARS-CoV-2 specific antibody responses in COVID-19 patients. medRxiv. 2020:2020.03.18.20038059.

21. Turkish Ministry of Health Immune Plasma Guidelines, 2020. Available from: URL: https://dosyamerkez.saglik.gov.tr/Eklenti/37163,covid-19-immun-plazma-rehberi-12-nisan-2020-sonv1-ti-neopdfpdf.pdf?0せ_tagl = D61DB6867EF68EE9A7FE73C870D9BBA04AACC05C.

22. Dennis McGonaglea,b,凹, KassemSharifa,c, Anthony O'Regand, Charlie Bridgewooda The Role of Cytokines including Interleukin-6 in COVID-19 induced Pneumonia and Macrophage Activation Syndrome-Like Disease Autoimmun Rev 2020 Apr 3;102537

23. Hendrickson JE, and Hillyer CD. Noninfectious serious hazards of transfusion. Anesth Analg. 2009; 108(3):759-69.

24. AABB. Standardsfor Blood Banks and Transfusion Services. Bethesda, MD: AABB; 2018.

25. Chang L, Zhao L, Gong H, Wang L, and Wang L. Severe Acute Respiratory Syndrome Coronavirus 2 RNA Detected in Blood Donations. Emerg Infect Dis. 2020;26(7).

26. Wang $W, X u Y$, Gao R, Lu R, Han $K, W u$ G, et al. Detection of SARS-CoV-2 in Different Types of Clinical Specimens. JAMA. 2020. Mar 11; e203786

27. Bloch EM, Shoham S, Casadevall A, Sachais BS, Shaz B, Winters JL, et al. Deployment of convalescent plasma for the prevention and treatment of COVID-19. J Clin Invest. $2020 \mathrm{Apr}$ 7:138745. doi: 10.1172/JCI138745. [Epub ahead of print]

28. Tetro JA. Is COVID-19 receiving ADE from other coronaviruses?. Microbes Infect 2020; 22(2): $72-3$.

29. Özdemir Ö, Melek Arsoy HE. Convalescent (Immune) Plasma Therapy with all Aspects: Yesterday, Today and COVID-19. Erciyes Med J 2020; 42(0): 00-00. 